\title{
Asthma prevalence among high school students in East Jakarta, 2001, based on ISAAC questionnaire
}

\author{
Faisal Yunus", Ratnawati Antaria", Menaldi Rasmin", Hadiarto Mangunnegoro", Anwar Jusuf", Adang Bachtiar **
}

\begin{abstract}
Abstrak
Penelitian ini bertujuan menilai prevalensi asma pada anak sekolah berumur 13-14 tahun di Jakarta Timur Penelitian ini bersifat survei cross sectional pada 2234 pelajar sekolah menengah berumur antara 13-14 lahun di Jakarta Timur pada tahun 2001 menggunakan kuesioner ISAAC. Uji provokasi bronkus menggunakan metakolin pada 186 pelajar. Berdasarkan kuesioner ISAAC didapatkan $7,2 \%$ pelajar mempunyai riwayat mengi. 4,1\% mengalami mengi dalam 12 bulan terakhir, $1.8 \%$ pernah mengalami serangan asma berat dalam 12 bulan terakhir, 3,3\% mengalami mengi sesudah latihan, dan 6,3\% mengalami batuk pada malam hari, sedangkan mereka tidak sedang menderita flu. Prevalensi penyakit atopi seperti rinitis dan eksim terdapat pada $14,2 \%$ dan $3.9 \%$ subjek, sedangkan prevalensi rinitis dan eksim dalam 12 bulan terakhir adalah 10.6\% dan 2,9\%. Secara statistik terdapat hubungan bermakna antara gejala mengi dan atopi $(p<0,05)$. Dari kuesioner nilai kappa bermakna 0,84 berhubungan dengan mengi dalam 12 bulan terakhir. Uji provokasi bronkus menunjukkan sensitivitas $90 \%$ dan spesifisitas $83,5 \%$, nilai prediksi positif $68.12 \%$ dan nilai prediksi negatif 95,7\%. Prevalensi asma di Jakarta Timur tahun 2001 berdasarkan kuesioner ISAAC adalah 8,9\% dan prevalensi kumulatif $11,5 \%$. Kuesioner ISAAC bisa digunakan untuk penelitian prevalensi asma pada anak sekolah di Indonesia. (Med J Indones 2003; 12: 178-86)
\end{abstract}

\begin{abstract}
The aim of this study was to assess asthma prevalence in children between 13-14 years of age in East Jakarta. This study is a cross sectional study which surveyed 2234 high school students between the ages of 13 and 14 years in East Jakarta in 2001 using the ISAAC questionnaire. Bronchial challenge test was applied by using methacholine substance to 186 students. Reports based on the ISAAC questionnaire indicate that 7,2\% of teenage have had wheezing experience, $4,1 \%$ have wheezing within the last 12 months, 1.8 $\%$ have ever suffered severe asthma attack within the last 12 months, 3.3\% have suffered wheezing after exercise, and $6.3 \%$ have got night cough while they were not suffering from cold. Prevalence of atopy diseases such as rhinitis and eczema were $14.2 \%$ and $3.9 \%$. meanwhile rhinitis and eczema prevalence within the last 12 months according to this study were $10.6 \%$ and $2.9 \%$ respectively. Statistically, there is a significant correlation between wheezing symptom and atopy $(p<0.05)$. From indepth quesionnaire, a significant value of kappa 0.84 related with wheezing within the last 12 months was found. Bronchial challenge test results indicate that sensilivity was $90 \%$, specificity $83.58 \%$, positive predictive value $68.12 \%$ and negative predictive value was $95.73 \%$. Asthma prevalence in East Jakarta at 2001 based on ISAAC questionnaire was $8.9 \%$, and cumulative prevalence $11.5 \%$. The ISAAC questionnaire can be used to study asthma prevalence in children at multicenter in Indonesia. (Med J Indones 2003; 12: 178-86)
\end{abstract}

Keywords: bronchial challenge, high school student, ISAAC questionnaire, East Jakarta, asthma prevalence

Asthma is a chronic respiratory tract disease that could happen at all ages and could be severe and fatal. More than 100 million people all over the world have suffered from asthma and the prevalence among

\footnotetext{
- Department of Respiratory Medicine. Faculty of Medicine, University of Indonesia, Persahabatan Hospital, Jakarta, Indonesia.

"Public Health Division, Faculty of Public Healih. University of Indonesia, Jakarta, Indonesia
}

children is on the increase. 'Although asthma is not a new disease (it has been known for a long time), its causes are still not clear. ${ }^{2}$

Asthma prevalence was increased both in adult and children all over the world. ${ }^{3-5}$ Globally the range of asthma prevalence was between $0-30 \%$ at different population.' In Oslo, the prevalence of asthma amongst children was increased within 13 years period of time (from $3.4 \%$ in 1981 to $9.3 \%$ in 1994). In Australia, asthma prevalence had increased more 
than two times in one decade, there is $10.4 \%$ in 1982 become $27.6 \%$ in $1992 .^{4}$ While in Taiwan the prevalence of asthma had amplified from $1.30 \%$ in 1974 and tum out to be $5.07 \%$ in 1985 and $5.80 \%$ in 1991. In England, asthma prevalence amongst children 12 years of age had also increased from 17\% - $22 \%$ during 15 years. ${ }^{6}$ Usually, the researcher define asthma diagnosis based on its symptom within the last 12 months. $^{7}$

In Indonesia, asthma is one cause of high morbidity after infection. ${ }^{8}$ Asthma prevalence in children vary from one place to another. In several big cities, the range is between $2.1 \%{ }^{9}$ to $22.2 \% .^{10}$ According to the Indonesian Household Health Survey (HHS) 1986, asthma, bronchitis, and other respiratory diseases ranks fifth as the cause of morbidity and tenth among the cause of death. Meanwhile, according to HHS 1992, asthma, bronchitis, and emphysema ranks seventh as the cause of death in Indonesia. ${ }^{8}$

Asthma prevalence among countries is difficult to compare since the studies often use different questionnaires. This difficulty highlights the need for one standard method, which could be applicable for monitoring asthma trends and comparing prevalence internationally and regionally. Such standard method " could help physicians and public health experts to take action to reduce asthma prevalence, which has dramatically increased in recent times. Quite recently the Steering Committee of International Study of Asthma and Allergies in Childhood (ISAAC) has developed a standard procedure for study on asthma prevalence, which could be used universally in different languages and geographical areas, making cross-country and regional comparisons possible. ${ }^{7,11}$

A previous literature did mention that asthma prevalence in children in Indonesia is lower than in other countries. ${ }^{9}$ In order to avoid having high number of asthma cases in children as in other countries, Indonesia must develop strategies that could ensure effective monitoring and control of asthma cases in future. This of course requires a sustainable study to ascertain the rate tendency of asthma and prevalence in children in Indonesia.

Study method comprised the use of ISAAC questionnaire, which has been translated into Bahasa Indonesia. Results of this study may assist in identifying asthma disease pattern in Indonesia. It may also help to unravel some of the underlying factors responsible for the growing incidence of asthma in many countries. The success of current and future preventive efforts particularly in developing countries depends very much on our knowledge of such underlying factors.

\section{METHODS}

\section{Design}

Cross sectional study and continued with diagnostic test. The study was conducted at selected high schools in Eastem part of Jakarta. Methacholine challenge was carried out at asthma clinic in Persahabatan Hospital, Jakarta surveying 186 students. The time frame was from April to September 2001.

Target population of this research consists of teenage students in Indonesia. High school students of 13 to 14 years of age were targeted because such students from both public and private schools in East Jakarta are easily accessible. A sample of students was taken randomly from a total number of 119,105 students which enrolled in 256 high schools in Eastern part of Jakarta. In all 2400 students from 60 different schools were selected. The age range of these students during the study was supposed to be from thirteen years or more to fifteen years or less ( $\geq 13-\leq 15)$.

\section{Procedure}

Multistage random sampling technique was adopted in this study. Firstly, 60 out of the 256 high schools in Eastern Jakarta were selected using simple random sampling method. Then a computer based program was used to randomly select subject study. In each school were distributed 40 sets of questionnaire. The questionnaires were given to selected students to be filled in by them. Prior to the distribution of the questionnaires, respondents were given a brief lecture on asthma and its symptoms such as wheezing, cough, dyspnea, as well as rhinitis and eczema, and were also given clear instructions as to how to fill in the questionnaire. Respondents were given the opportunity to take the questionnaires home and return them the next day through their teachers in case they are not sure about the answers they are providing. Complete questionnaire were categorized into 3 groups namely asthma within the last 12 months, asthma and non-asthma groups. Three months later, a follow-up interviews were conducted, 459 students were asked similar questions as those in 
the original questionnaire by the research $l$ in order to measure the value agreement (kappa).

Some students were selected at random from both asthma and non-asthma groups for the next stage of the study, which was the examination of how their pulmonary function and the bronchial challenge test. Bronchial challenge test was performed on some selected and non-selected but willing students. All the students for the test were supposed to meet the following conditions:

1. Subjects should be asymptomatic, do not have medical treatment which would interfere with bronchial challenge test such as $ß 2$-agonist or anticholynergic MDI $<4$ hours, teophyline or oral antimuscharinic $<8$ hours. ${ }^{12}$ Antihistamine $<24$ hours and theophylline slow release $<48$ hours. Asthma patients using corticosteroid could continue using ordinary dose. ${ }^{13}$

2. VEP, before test should be $>80 \%$ from predictive value based on Indonesia Pneumobile Project, 1992.

3. Subjects should not be under exacerbation or asthmatic status, cooperative and should not be suffering from pulmonary diseases, which cause severe pulmonary dysfunction.

After obtaining the results of the bronchial challenge test, sensitivity, specificity, positive predictive value (PPV), and negative predictive value (NPV) were calculated by using two times two tables. Data were analyzed using SPSS 10.0 statistical package program.

The study was licensed by East Jakarta Regional Office of Department of Education, which also assisted through writing of letters to heads of schools to request for their co-operation. The informed consent from parents of students who were willing to participate in the bronchial challenge test were sought through their teachers Ethical clearance was given by authority board.

\section{RESULTS}

\section{Questioner responses}

Of 2400 questionnaires that were distributed to the students, $2234(93.08 \%)$ were filled out and returned. These comprised of 969 (43.4\%) questionnaires from male (boys) respondents and $1265(56.6 \%)$ from female (girls) respondents. Eight hundred and sixty questionnaires (38.5\% of total questionnaire) were received from respondents' aged of 13 years. Fourteen
(14) year old respondents returned a total of 1374 $(61.5 \%)$ questionnaires. This is illustrated in the table below (table 1).

Table 1. Response of ISAAC questionnaire 13-14 years old

\begin{tabular}{lllll}
\hline & & \multicolumn{3}{c}{ Sex } \\
\cline { 3 - 5 } & & Boy & Girl & Total \\
\hline \multirow{3}{*}{13 years old } & Age( $\%)$ & $42,6 \%$ & 594 & 860 \\
& Sex (\%) & $37,8 \%$ & $39,1 \%$ & $100 \%$ \\
& & & & $38,5 \%$ \\
14 years old & & 603 & 771 & 1374 \\
& Age(\%) & $43,9 \%$ & $56,1 \%$ & $100 \%$ \\
& Sex (\%) & $62,2 \%$ & $60,9 \%$ & $61,5 \%$ \\
\hline Total & & & & \\
& & 969 & 1265 & 2234 \\
& Age(\%) & $43,4 \%$ & $56,6 \%$ & $100 \%$ \\
& Sex (\%) & $100 \%$ & $100 \%$ & $100 \%$ \\
\hline
\end{tabular}

Based on symptoms quesionnaire (table 2), asthma sufferers within the last 12 months were 199 students $(8.9 \%)$ consisting of 92 boys $(46.2 \%)$ and 107 girls $(53.8 \%)$. These numbers were derived from a combination of answers supplied by respondents to questions number 2 (wheezing within the last 12 months), 7 (wheezing during or after exercise within the last 12 . months) and 8 (wheeze/cough at night within the last 12 months). Cumulative wheezing, which was the combination of answers to questions number $1,2,6,7$, and 8 was found to be 257 students $(11.5 \%)$ which comprises of 117 boys $(45.5 \%)$ and 140 girls $(54.5 \%)$ (Figure 1$)$.

Answers provided to question relating to rhinitis indicate that 317 students $(14.2 \%)$ have rhinitis history. They comprised of 141 boys (44.5\%) and 176 girls $(55.5 \%)$, Respondents who have had rhinitis within the last 12 months were 236 students $(10.6 \%)$; they consisted of 104 boys $(44.1 \%)$ and 132 girls $(55.9 \%)$.

From eczema question it was found that $89(3.9 \%)$ students comprising of 31 boys (34.8\%) and 58 girls $(65.2 \%)$ have eczema history, while 66 students $(2.9 \%)$ made up of 21 boys $(31.8 \%)$ and 45 girls $(68.2 \%)$ have had eczema within the last 12 months.

Of 160 students who had wheezing history it was found that 103 students $(64.38 \%)$ also had atopy. They were made up of 84 students $(52.5 \%)$ who had rhinitis history and 19 students (11.9\%) with eczema. Statistically, it was found that significant correlation exist between wheezing, rhinitis and eczema. 
Table 2. Symptoms prevalence (\%)

\begin{tabular}{lcccc}
\hline \multicolumn{1}{c}{ Symptoms } & Boys & Girls & Total & Prevalence (\%) \\
\hline Historical wheezing & $77(48.1 \%)$ & $83(51.9 \%)$ & 160 & 7.2 \\
Wheezing within the last 12 months & $46(50 \%)$ & $46(50 \%)$ & 92 & 4.1 \\
Wheezing within the last 12 months & & & \\
Never & $7(7.6 \%)$ & $3(3.3 \%)$ & $10(10.9 \%)$ \\
$1-3$ times & $35(38 \%)$ & $33(35.9 \%)$ & $68(73.9 \%)$ \\
$4-12$ times & $3(3.2 \%)$ & $6(6.6 \%)$ & $9(9.8 \%)$ \\
$>12$ times & $1(1.1 \%)$ & $4(4.3 \%)$ & $5(5.4 \%)$ \\
Sleeping disorder caused by wheezing & & & \\
Never & $7(7.6 \%)$ & $12(13.1 \%)$ & $19(20.7 \%)$ \\
$<1$ night within a week & $30(32.6 \%)$ & $20(22.3 \%)$ & $50(54.3 \%)$ \\
$\geq 1$ night within a week & $8(8.7 \%)$ & $14(15.2 \%)$ & $22(23.9 \%)$ \\
Severe symptom within 12 month & $19(46.3 \%)$ & $22(53.7 \%)$ & 41 \\
Asthma historical & $66(46.4 \%)$ & $76(53.6 \%)$ & 142 \\
Wheezing during or after exercise & $33(44.5 \%)$ & $41(55.5 \%)$ & 74 & 1.8 \\
Night cough & $64(45.4 \%)$ & $77(54.6 \%)$ & 141 \\
& & & 6.4 \\
\hline
\end{tabular}

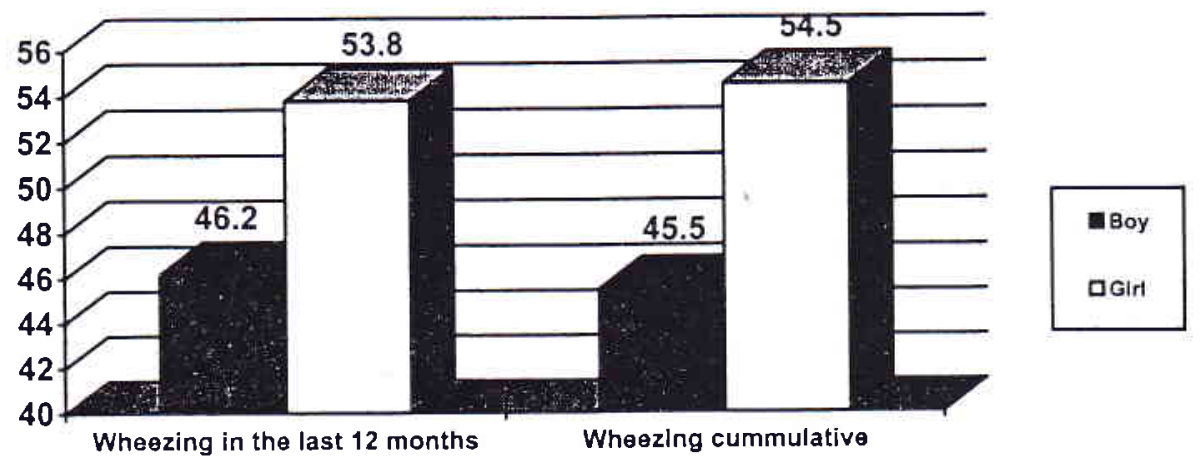

Figurel. Asthma prevalence within the last 12 months compare to prevalence of asthma cumulative

On the whole, answers provided by respondents were found to be in conformity with the researchers own knowledge about asthma prevalence in children in Jakarta. The agreement of question, which answer by them, and interview of asthma experience were found about 0.76 for wheezing experience and 0.84 for wheezing within the last 12 months.

\section{Bronchial challenge test}

Bronchial challenge test was carried out using methacholine which have $\mathrm{VEP}_{1} \geq 80 \%$ at spyrometri test. The 186 students who were selected and were willing to participate in the bronchial test were comprised of 82 boys (44.1\%) and 104 girls $(55.9 \%)$.
Table 3 shows the results of bronchial challenge test using methacholine to the three groups of students. The results of this study also demonstrate that negative bronchial chalienge test was found in 12 students $(57.1 \%)$ with positive experience of wheezing, 112 students $(95.7 \%)$ who do not have wheezing experience and $10(20.8 \%)$ who have had wheezing experience within the last 12 months.

Out of the 19 students (10.2\%) who reported wheezing after exercise, it was found that 3 of them $(15.8 \%)$ have negative BHR, while, $16(84.2 \%)$ have positive BHR. Of the 167 students who reported never had wheezing after exercise, the study found that 36 of them $(21.6 \%)$ have positive BHR while the rest, 
$131(78.4 \%)$ were found to have negative. Statistically, there is a significant correlation between wheezing after exercise and BHR $(p<0,001)$.

In order to measure validity of questionnaire, bronchial challenge test was carried out as a golden standard of asthma diagnose. The bronchial challenge test in this study was carried out to 186 students of which 69 were asthmatic and 117 were nonasthmatic. Of the 69 asthmatic students, 47 of them $(68.1 \%)$ had positive BHR. Nine of the 47 had wheezing experience and 38 (80.9\%) have ever had wheezing within the last 12 months. Only 5 out of the 117 non-asthmatic students were found to have positive BHR. The correlation between questionnaire and bronchial challenge found that sensitivity value was about $90 \%$, specificity $83.58 \%$, PPV $68.12 \%$ and NPV $95.73 \%$.

\section{DISCUSSION}

\section{Questionnaire}

This cross sectional study was conducted in Jakarta. To ensure that the sample is a true representative of the target population, a simple random sampling technique was used to select respondents. The purpose of using ISAAC questionnaire for this survey was to make it simple for respondents to answer questions by themselves. The ISAAC questionnaire uses ordinary language and uncomplicated medical terminology. It also has a high level of sensitivity and specificity that has been tested in 156 countries and at 156 asthma centers with different environment and languages. Besides, ISAAC questionnaire was developed with the intention to avoid misanswer or denials in answering questions by respondent.

Most of epidemiological researches on asthma prevalence are based on subjective judgment of respondents. The weaknesses of researches which use questionnaire, as a tool is the possible bias of memory. Answering the same question twice at different period of time could provide knowledge of "how far are the differences of understanding of asthma with regard to wheezing terminology". Bias of memory usually happens to students who have light and rare asthma symptom within the last 12 months of period (current asthma). The results of both test on continuous wheezing experience showed the degree of appropriateness was significant, about 0.76 , and with a question of wheezing experience within 12 months was 0.84 . These findings suggest that, there is a high degree of agreement between answers provided in the first and second interviews. It proves that questionnaire can be used as a device for measuring asthma prevalence in children.

\section{Asthma Prevalence}

As several asthma researches in Jakarta have demonstrated, asthma prevalence in high school students is lower than in primary school pupil. Similar findings were made by various researches in other countries but the underlying causes of this phenomenon is still unknown.

A comparison of asthma prevalence among countries has long been difficult. This is due to the fact that different studies use different questionnaire and research technique. Compare with previous researches on asthma prevalence in Indonesia, such as the study of asthma in high school students in Central Jakarta, Semarang, Palembang, and other researches conducted outside Jakarta, this study indicates that asthma prevalence in Eastern Jakarta is higher (Figure 2). Comparing it to the study on teenagers of 13 to 14 years of age in Bandung which also used the ISAAC questionnaire, it can be observed that asthma prevalence in Jakarta is higher than in Bandung.

Table 3. The result of bronchial challenge test

\begin{tabular}{cccc}
\hline Group & BHR $(+)$ & BHR $(-)$ & Total \\
\hline Wheezing experience $(+)$ & $9(42.9 \%)$ & $12(57.1 \%)$ & $21(11.3 \%)$ \\
Wheezing experience $(-)$ & $5(4.3 \%)$ & $112(95.7 \%)$ & $117(63 \%)$ \\
Wheezing within the last 12 months & $38(79,2 \%)$ & $10(20,8 \%)$ & $48(25,7 \%)$ \\
\hline Total & $52(28 \%)$ & $134(72 \%)$ & $186(100 \%)$ \\
\hline
\end{tabular}


Prevalence of Asthma at High School Student in Indonesia

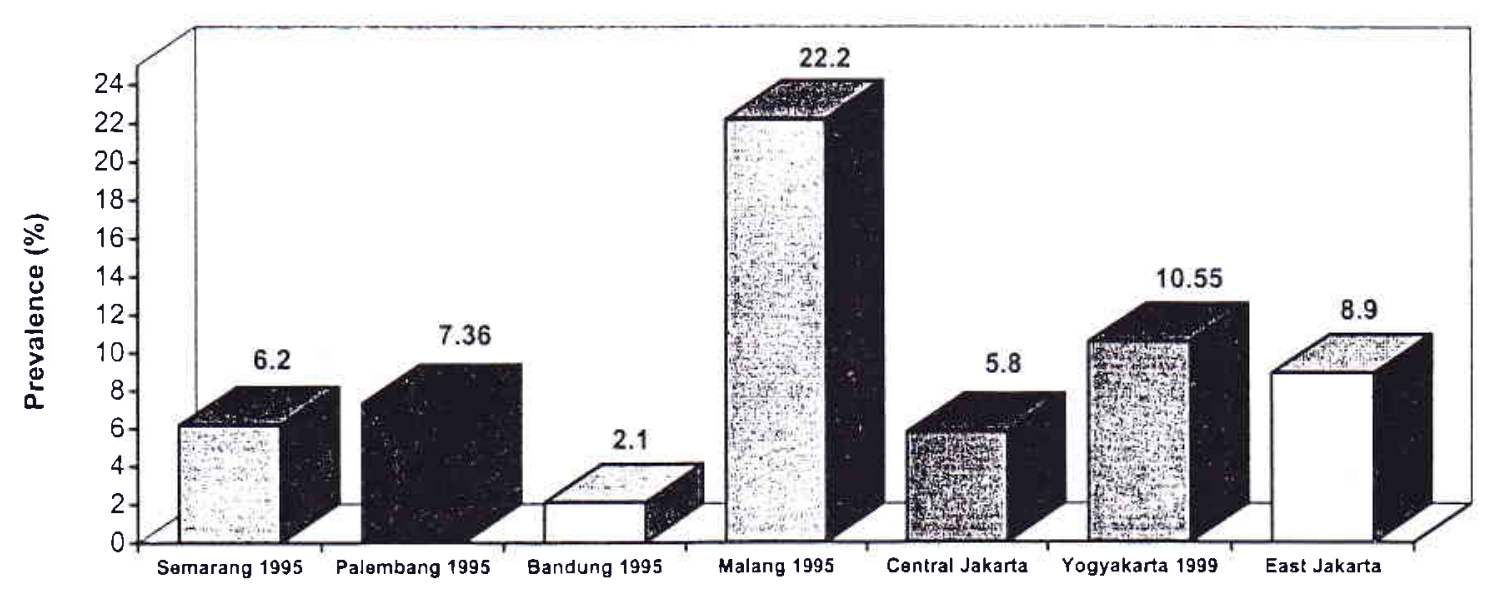

Figure 2. Prevalence asthma of school children at several cities in Indonesia

Viral infection during childhood could become a predisposition factor, which may cause decreasing immune response Th2, causing IgE production to reduce. ${ }^{15}$ The high incidence of viral infection among children in Indonesia seems to be one of underlying factors contributing to the low asthma prevalence compare to prevalence in the developed world. Some studies have concluded that children who seldom suffer from infection during their underfive years of age would have higher risk of asthma infection during their school age. ${ }^{10}$

A multicenter study by ISAAC in 56 countries found prevalence of rhinitis allergy to be between $1.4 \%$ $39.7 \%$, and prevalence of eczema to be about $0.3 \%$ $20.5 \%$. The study stated that centers with low prevalence of eczema usually also have low asthma prevalence and symptom of rhinitis. ${ }^{9}$ In this study, the prevalence of rhinitis in high school students in Jakarta was found to be slightly high (14.2\%), while in contrast, prevalence of eczema was low $(3.9 \%)$.

As declared thinitis allergy and asthma are chronic diseases that could emerge together especially in children. There are several factors, which are already known related to asthma and rhinitis. It is for instance known that asthma and allergy thinitis have the same genetic predisposition, and similar respiratory tract mucous. Inflammation is the important factor in either asthma or rhinitis pathogenesis. A bearer of allergy rhinitis often suffers from asthma exacerbation in autumn when plants begin to pollinate. Furthermore, allergy reaction in the nose mucous would activate asthma symptoms. Effective treatment of rhinitis may reduce the asthmatic symptoms. ${ }^{17}$

Corren ${ }^{18}$ concludes that upper and lower respiratory tract infection could occur together. Symptom of rhinitis was reported higher in asthma patients (28$78 \%$ ) compare to the general population (20\%). About $19-38 \%$ of allergy thinitis patients were suffering from asthma. Of all respondents of this study who have wheezing experience, it was observed that about $84(52.5 \%)$ have rhinitis and $19(11.9 \%)$ have eczema. Therefore, statistically, there is a significant relationship between wheezing and atopy (rhinitis and eczema).

\section{Bronchial challenge test}

Bronchial challenge test is often used in epidemiological study as the golden standard of asthma diagnose. This test employs non-specific provocation substance. With regards to children with asthma, most of them show positive BHR, but in nonasthmatic children, majority of them show negative BHR.

In this study, the bronchial challenge test revealed that 52 students have positive HBR; they consist of 31 girls $(59.6 \%)$ and 21 boys $(39.4 \%)$. This is similar to the results of the bronchial challenge test at the 
community level done by Leynaert, ${ }^{19}$ which concluded that the number of BHR is greater in women than in men since a diameter of womens' lung and respiratory tract is smaller than men.

The results of this study also show that people who have experience wheezing within the last 12 months have a greater chance of suffering HBR than those who have asthma or no-asthma. With respondents classified as asthmatic according to the answers they supplied, the bronchial challenge test revealed that $57.1 \%$ has negative bronchial hyperactivity to the students who has ever had asthma and $20.8 \%$ in the group of current asthma. The differences could be due to several factors including memory bias. Respondents who have suffered from asthma long time ago, might have wrong perceptions of the disease, or they really might not have BHR or perhaps it is caused by sensitivity and specificity, which are much clearer in bronchial challenge test than in using questionnaire.

The results of this study also show that $4.3 \%$ of those students, who do not have wheezing experience, have positive BHR. This means that $4.3 \%$ of students have asymtomatic BHR. Other studies have already shown that people with asymtomatic airway hyperresponsiveness have greater chance of getting asthma than people who do not have airway hyperesponsiveness. ${ }^{20}$ Epidemiological study done by Palmer et.al ${ }^{21}$ pointed out that increasing hyperesponsiveness of respiratory tract at early stages of life is a strong prediction of critical asthma disease in the future and other respiratory symptoms. It could also become a signal that a baby has a risk factor of asthma and permanent wheezing during their childhood period.

Physical activity is one of the trigger factors, which may cause acute obstruction of respiratory tract known as exercise-induced bronchospasm. This problem is more likely to occur in children rather than teenagers, and it is due to the fact that children have more physical activity. Researches in other countries have reported that exercise prevalence as trigger cause of asthma symptom is very high in the range of $40 \%$ $90 \%{ }^{22}$ In this research, wheezing after exercise occurred in 74 respondents (3.3\%) and using statistical arithmetic, it was found that there is a significant relationship between wheezing and exercise which is shown as BHR reaction. Cabral et.al ${ }^{22}$ have proved that exercise-induced bronchospasm is more likely to occur in children with more severe asthma symptom, and the degree of asthma symptom as a result of exercise does not have reliable relationship with the level of clinical asthma symptom.

In this study, after the subjects have had the bronchial challenge test, some of them suffered from minor side effects such as chest discomfort ( 6 persons or $3.8 \%$ ), cough ( 5 persons or $3.1 \%$ ), headache ( 2 students or $1.2 \%$ ) and wheezing ( 5 apprentices or $3.1 \%$ ). These side effects can be treated with bronchodilator substances. None of the respondents suffered from loosing his/her sound after being tested, as reported by previous researcher who used histamine as a provocation material. ${ }^{23}$ Eventhough, a measurement of pulmonary function is difficult to perform in children, in this study only one student whose lung function could not be measured because he was uncooperative.

Smoking should be restrained since it is the main cause of respiratory diseases, however, its role as an origin of asthma is still not clear. In several surveys, smoking among population has been linked to hyperesponsiveness of respiratory tract. Smoking can cause temporary hyperesponsiveness respiratory tract in normal people. Passive smoking could increase hyperesponsiveness of respiratory tract in adult asthma patients, however, asthma patients with smoking cessation show decreasing hyperesponsiveness respiratory tract. On the whole, there is little evidence that smoking in adults increases asthma.$^{24^{*}}$ This research found that three students with positive BHR have had smoking experience. In addition, two students with asthma mentioned, "they do not believe smoking of cigarette can trigger asthma attack." (Data not displayed). Their perceptions might be due to the fact that they only suffer from light asthma and have had only short-term exposure to cigarette smoking considering their age. ${ }^{24}$

In epidemiological research, asthma could be diagnosed by looking for symptoms and signs such as wheezing experience, wheezing which is provoked by certain stimulus, statement that he/she is suffering from asthma, and history of asthma that is confirmed by a doctor. In this research, wheezing or asthma within the last 12 months was used as asthma definition. By conducting the bronchial challenge test, values diagnostic questionnaire in this study were close to those of a study conducted in Australia by Jenkins et.al ${ }^{25}$ using the ISAAC questionnaire This is a further proof that questionnaire is an effective apparatus for research on asthma prevalence at the 
community level. It has high specificity, very practicable, easy to do, simple, and relatively inexpensive.

\section{CONCLUSION}

1. The result of the study demonstrates that asthma prevalence among high school children of 13 to 14 years in Eastern Jakarta in 2001 was about 8.9\%, while cumulative prevalence was $11.5 \%$.

2. By using Bronchial Challenge test this study found that sensitivity of ISAAC questionnaire was $90 \%$. However its specificity was found to be $83.58 \%$, while positive predictive value 68.12 and negative predictive value were $68.12 \%$ and $95.73 \%$ respectively.

3. Prevalence of rhinitis and eczema were $14.2 \%$ and $3.9 \%$, meanwhile rhinitis and eczema prevalence within the last 12 months were $10.6 \%$ and $2.9 \%$ respectively. There is a significant correlation between wheezing symptom and atopy.

4. This study has shown that questionnaire is a good instrument for measuring asthma prevalence in epidemiological survey in Indonesia.

5. The results of this study could be used as basis for monitoring asthma prevalence in the future.

\section{Acknowledgments}

This work was supported by the Agency for Research and Development, Ministry of Health, Republic of Indonesia.

\section{REFFERENCES}

1. Global Initiative for Asthma. Global strategy for asthma management and prevention. NHLBI / WHO Workshop Report. National Institute of Health. Publication number 95-3659, 1995; 1-176.

2. European Community Respiratory Health Survey. Variations in the prevalence of respiratory symptoms, selfreported asthma attacks, and use of asthma medication in the European Community Respiratory Health Survey (ECRHS). Eur Respir J 1996; 9: 687-95.

3. Nystad W, Magnus P, Gulsvik A, Skarpaas JK, Carlsen $\mathrm{KH}$. Changing prevalence of asthma in school children: evidence for diagnostic changes in asthma in two surveys 13 yrs apart. Eur Respir J 1997; 10: 1046-51.

4. Pearce N, Weiland S, Keil U, Langridge P, Anderson HR, Strachan D, et al. Self-reported prevalence of asthma symptoms in children in Australia, England, Germany and
New Zealand: an intemational comparison using the ISAAC protocol. Eur Respir J 1993; 6: 1455-61

5. Zhong NS. New insights into risk factors of asthma. Respirology 1996; 3: 59-66.

6. BurT ML, Butland BK, King S, Williams EV. Changes in asthma prevalence: two surveys 15 years apart. Arch Dis Child 1989; 64: 1452-6.

7. Kemp T, Pearce N, Crane J, Beasley R. Problems of measuring asthma prevalence. Respirology 1996; 3: 183-8.

8. Department of Health Republic of Indonesia. Health situation in Indonesia. In: Indonesian Health Profile 1997. Department of Health RI, Jakarta, 1997; 49-101.

9. The International Study of Asthma and Allergies in Childhood (ISAAC) Steering Committee. Worldwide variations in the prevalence of asthma symptoms: the International Study of Asthma and Allergies in Childhood (ISAAC). Eur Respir J 1998; 12: 315-35.

10. Chandra HMS, Muid M, Mardhani YS, Sumakto N, Santoso NB. (Abstr) Asthma prevalence and its risk factors in high school students in Malang. Delivered on the tenth Congress of Pediatrics, Bukit Tinggi, June 16-20 1996.

11. Kaur B, Anderson HR, Austin J, Burr M, Harkin LS, Strachan DP, et al. Prevalence of asthma symptoms, diagnosis, and treatment in 12-14 years old children across Great Britain (International Study of Asthma and Allergies in Childhood, ISAAC UK). BMJ 1998; 316:118-24.

12. Chinn S, Burney P, Jarvis D, Luczynska C. Variation in bronchial responsiveness in the European Community Respiratory Health Survey (ECRHS). Eur Respir J 1997; 10: 2495-501.

13. Yunus F, Wirjokusumo R, Mangunnegoro $H$. Bronchial hyperresponsiveness pattern of obstructive airways deseases patients. Paru 1989; 9: 13-9.

14. Republika. Jakarta is the most polluted city in the world, 3 April 1996

15. Von Mutius E, Llli S, Hirsch T, Leupold W, Keil U, Weiland S. K. Frequency of infections and risk of asthma, atopy and airway hyperresponsiveness in children. Eur Respir J 1999; 14: 4-11.

16. Mochizuki H, Shigeta M, Arakawa H, Kato M, Tokuyama $\mathrm{K}$, Morikawa A. Bronchial hyperresponsiveness before and after the diagnosis of bronchial asthma in children. Pediatrics 2000; 106:1442-6.

17. Fireman P. Therapeutic approaches to allergy rhinitis: treating the child. J Allergy Clin Immunol 2000; 105 (Suppl): 616-21.

18. Corren J. Allergic rhinitis and asthma: How important is the link?. J Allergy Clin Immunol 1997; 99(Suppl): 781-6.

19. Leynaert B, Bousquet J, Henry C, Liard R, Neukirch F. Is BHR more frequent in women than in men?. Am J Respir Crit Care Med 1997; 156: 1413-20.

20. Laprise C, Boulet LP. Asymptomatic airway hyperresponsiveness: A three-year follow-up. Am J Crit Care Med 1997; 156: 403-9.

21. Palmer LJ, Rye PJ, Gibson NA, Burton PR, Landau LI, Lesouef PN. Airway responsiveness in early infancy predicts asthma, lung function and respiratory symptoms by school age. Am J Respir Crit Care Med 2001; 163: $37-45$.

22. Cabral ALB, Conceicao GM, Fonceca-Guedes CHF, martins MA. Exercise-induced bronchospasm in children, effects of asthma severity. Am J Respir Crit Care Med 1999; 159: 1819-23. 
23. Clifford RD, Radfort $M$, Howell JB, Holgate ST. Prevalence of atopy and range of bronchial response to metacholine in 7 and 11 year old schoolchildren. Arch Dis Child 1989; 64: 1126-32.

24. Burney PGJ. Epidemiology. In: Clark TJH, Godfrey S, Lee $\mathrm{TH}$ editors. Asthma. $3^{\text {th }}$ ed. Chapman \& hall Medical, London, 1992; 254-89.
25. Jenkins MA, Clarke JR, Carlin JB, Robertson CF, Hopper $J L$, Daiton MF, et al. Validation of questionnaires and BHR against respiratory physician assessment in the diagnosis of asthma. Int J Epidemiol 1996; 25: 609-16. 